Article

\title{
Integrated Management Approach Towards Sustainability: An Egyptian Business Case Study
}

\author{
Gianluca Vitale ${ }^{1,2, *}$, Sebastiano Cupertino ${ }^{1, *}$ (D) , Loredana Rinaldi ${ }^{1,2}$ and Angelo Riccaboni ${ }^{1}$ (i) \\ 1 Department of Business and Law studies, University of Siena, Piazza San Francesco, 8, 53100 Siena, Italy; \\ loredana.rinaldi2@unisi.it (L.R.); riccaboni@unisi.it (A.R.); \\ 2 Department of Economics and Management, University of Pisa, Via Cosimo Ridolfi, 10, 56124 Pisa, Italy \\ * Correspondence: gianluca.vitale@unisi.it (G.V.); cupertino@unisi.it (S.C.); Tel.: +39-0577-232658
}

Received: 25 January 2019; Accepted: 18 February 2019; Published: 26 February 2019

\begin{abstract}
Several studies have focused mainly on the following approach to tackle sustainable development issues at the management level: single sustainability managerial tools adoption (e.g., sustainable balance scorecard) and the "overlap" process between traditional management practices and sustainability-oriented ones. Conversely, integration as an "alignment" process between different sustainability management practices represents a research field, which is currently underinvestigated. Filling this gap, the purpose of the present study is to deepen and find empirical evidence on how sustainability management accounting, control, and reporting systems can be integrated through an alignment process. To this aim, we focused our analysis on a Mediterranean holding company, which is a well-known sustainable corporate practitioner to foster sustainable development in a socioeconomic and environmental problematic context. Therefore, we developed a single business case study analyzing an Egyptian firm to give practical evidence on the role of management accounting, control, and reporting practices in addressing sustainability issues. The analysis shows that the aligning process of different management practices involves a plurality of business aspects to manage, among them cultural and organizational ones. Despite its complexity, such a process is fundamental to pursue medium-long-term goals, ensuring sustainable firm growth and social wellbeing.
\end{abstract}

Keywords: sustainable development; sustainable KPIs; sustainable accounting \& control; sustainability reporting; managerial integration; PRIMA programme; case study

\section{Introduction}

During the last few decades, both scholars and practitioners have increased their awareness about the strategic role played by firms in supporting sustainable economic growth. In this regard, the launch of the UN Agenda 2030 endorsed the need for more socially responsible firms. The latter are strongly invited to achieve Sustainable Development Goals (SDGs) [1] with the aim of tackling the current economic and socioenvironmental challenges.

In particular, firms are strongly invited to cooperate with other public and private partners, to carry out innovative activities enhancing the common wellbeing. Therefore, such firms are currently called to change their internal processes with the aim to increase their environmental, social, and governance (ESG) performance, achieving a competitive advantage as well [2]. However, this business attitude is not so easy to operationalize. In this regard, the clear definition of a sustainability-oriented corporate strategy as well as the related change in accounting and control systems could lead companies to harness economic interests while simultaneously achieving better sustainability performance [3]. Moreover, the alignment of the corporate purpose (that is, the company's reason of being) with 
sustainable development criteria can allow managers to define well and communicate the company's values as well as mitigating reputational risks [4].

In-line with this, such corporate cultural and technical preconditions can help to embed the sustainability principles in all managerial actions and practices, minimizing possible negative externalities. To this end, firms are called to balance nonfinancial objectives with the more traditional financial ones, trying to preserve the interests of many stakeholders [5,6]. Consequently, managers should effectively run sustainable businesses in a multidimensional perspective, (re)defining traditional management accounting and control systems, key performance indicators (KPIs), and reporting activities [7]. As result, firms, both the biggest and the medium-smallest ones (e.g., Falle et al. [8]), are changing their internal practices in order to integrate sustainability issues into company management.

However, the implementation of single management initiatives is no longer enough to address all the sustainability challenges firms are called to face. In this regard, recent studies have called for a more integrated approach in the use of management tools $[9,10]$ both to better tackle sustainability issues and to prevent possible distortive effects that single and isolated management practices could have on business [9]. To this end, accounting, management control, and reporting should simultaneously shift towards sustainability and be fully aligned in order to concretely support managers in making a sustainable strategy operative [11]. However, the alignment of such systems is a tricky process. Generally, the integration of traditional management and accounting practices with sustainability issues is characterized by several interrelated technical, organizational, and cognitive aspects [9]. In light of this, prior studies assumed the integration of sustainability issues in existing management tools and practices to be an "overlapping" process [9,10,12-14]. On the other hand, very few studies considered the integration between sustainability-oriented management tools and practices as the result of an "alignment" process $[11,15,16]$. Therefore, following the suggestions of Maas et al. [11] to further investigate such "alignment" processes, the aim of this study is to contribute to the literature finding empirical evidence about this underinvestigated topic.

In-line with the abovementioned, this paper, adopting the Maas et al. (2016) theoretical framework, developed a case study investigating the integration modalities and dynamics of business sustainable management tools and practices. Specifically, the focus was on an Egyptian holding company that is largely recognized worldwide and in literature as an influential social enterprise [17-20] as well as an important corporate sustainable practitioner [21] in the South coast of the Mediterranean basin. In the context of the political, economic, and socioenvironmental issues that afflict this area, the selected firm is on the forefront of sustainability management practices. Since its foundation, indeed, it has cooperated with public and private partners, supporting local and international initiatives around the world to boost sustainable economic growth. To that end, it is involved in the Partnership for Research and Innovation in the Mediterranean Area (PRIMA) program currently being implemented. The PRIMA initiative supports research and innovation public-private cooperation activities that are useful to implementing innovative solutions aimed at improving the efficiency and the sustainability of agri-food systems, as well as water provision in the Mediterranean Basin.

Differently from prior studies, the aim of this paper is to deeply analyze why and how an integrated process between the different management tools and practices occurs to enhance corporate sustainability in the long run. The paper is structured as follows: at first, a literature review on single management tools (accounting, control, and reporting) was carried out; in the second part, the theoretical framework and the need for an integrated approach fostering corporate sustainability is highlighted; the methodological approach is then described; and, finally, the empirical case study is developed. The paper ends with some discussions and conclusions giving theoretical and managerial implications, as well as future research developments. 


\section{Literature Review}

\subsection{Sustainability Accounting}

Management accounting is the process of identifying, measuring, accumulating, analyzing, preparing, interpreting, and communicating information that helps managers to both make decisions and plan and control business activities [22]. According to this definition, the core of management accounting is represented by information. The latter, traditionally, derives from a series of measures and indicators that express particular economic and financial business results (e.g., return on equity, return on assets, profit margin, and debt ratio).

Despite its usefulness in supporting manager decision-making activities, several authors in the literature have highlighted different limits of conventional accounting practices (see, e.g., Gray et al. [23], Gwilliam et al. [24]). One of the main critical issues of conventional accounting is that it is excessively based on quantitative monetary parameters, proving to be scarcely suitable for assessing business environmental impacts and sustainability results [25]. In recent years, given the increasing attention of stakeholders and institutions to sustainability issues, such criticism has been increasingly felt by firms, which have started to implement additional accounting tools for measuring environmental and social performance with the aim to balance these aspects with the economic dimension [26]. In light of this, sustainability accounting can be defined as the set of activities, methods, and systems used to record, analyze, and report corporate sustainability-related information (see Battaglia et al. [10], Giovannoni and Maraghini [14]). Therefore, the integration of corporate sustainability accounting practices in conventional activities could be an innovative evolution at the management level, particularly for planning, control, and evaluation activities. This organizational innovation process is fundamental to better manage the business impacts on the society and the environment [27].

\subsection{Sustainability Management Control}

Management control, in its broadest sense, can be defined as the organic set of tools, processes, roles, and informal solutions aimed at driving the behavior of managers and business operators towards the achievement of the overall organizational goals $[28,29]$. In the last three decades, the concepts of accounting and management control have often been flanked and defined as a whole, rather than separate and isolated topics [30]. Nevertheless, there is a substantial difference between the two concepts. Accounting focuses on information, while management control is based on the mechanisms through which managers direct the behavior of workers towards the desired actions and the strategic objectives planned. Since corporate goals derive from the company's basic strategic approach, management control mechanisms ensue from business strategy, supporting its operationalization and allowing its correction and readjustment [31]. Corporate strategy is commonly based on those planned actions to achieve economic and financial business results. Recently, however, such a concept has become limiting, as it is becoming increasingly important to integrate the economic aspects with those of sustainability that, in turn, must become an integral part of the overall strategic approach of the organization (2). In the light of this, management control systems also need to evolve and reshape their traditional aims and function, addressing environmental and social issues as well $[9,15]$. Therefore, in literature, some authors have introduced the concept of sustainability management control. Nevertheless, scholars have still not produced a definition or an organic debate about this theme to date [32].

In particular, some studies have dealt with environmental management and ecocontrol as forms of management mechanisms to monitor and assess the physical impact of business activities produced on environment (e.g., Schaltegger and Burritt [33], Henri, J.-F. and Journault [34]). In other words, the sustainability control system seems to be a parallel mechanism to the traditional management control systems (MCSs), which focus on sustainable performance. However, at the same time, these managerial mechanisms need to not remain isolated, but they must interact with traditional management control 
systems to allow effective integration of sustainability logic into the company strategy $[9,35]$. Such an approach could be misleading regardless, since the separation of the two forms of controls could lead to the adoption of merely symbolic behaviors, very different from the concrete integration of sustainability principles within the company strategy and activities.

In our view, reading along the line of the body of previous studies, a sustainability management control system should be considered as an advancement of the existing ones, since it should be built on the existing management control architecture. In light of this, sustainability management control could be defined as the set of tools and practices useful to operationalize sustainable strategies and to ensure a balanced achievement of the economic, social, and environmental corporate performance. According to this line of thinking, the entire business management control system could be understood as a "package" in which there is a "continuum" between traditional control mechanisms and sustainability management control logic, supporting the implementation of an effective sustainable business governance.

\subsection{Sustainability Reporting}

In literature, we could find several meanings and uses about reporting related to specific internal and external accounting and management practices. The present study, as regard the term of reporting, refers to external financial and nonfinancial disclosure activities and tools. To this end, reporting activities differ from management control and accounting practices, since they manage data that cross company boundaries, disclosing the main business performance to the stakeholders. Today, both scholars and practitioners agree that traditional disclosures do not provide a clear and holistic overview of corporate value [36]. The information disclosed in these statements refers to financial activities and show the company's financial position at a specific date or its financial inflows or outflows in a precise period [37].

Irrespective of this, traditional disclosures have been considered insufficient in providing the whole range of information needed by investors and stakeholders [38,39]. Focusing almost exclusively on business profitability and financial indicators may not guarantee long-term growth and business success [40]. For this reason, more nonfinancial information is needed in order to gain a wider perspective of overall business performance, including social and environmental aspects. This has led to a broader adoption of sustainability reports. Sustainability reporting was introduced around the early nineties, when the first environmental reports were published, mostly on a voluntary basis, to inform external stakeholders about environmental implications of business activities [41]. Over the years, this reporting process has been extended to also include social and financial aspects [41], becoming an element of assessment and communication of an organization's sustainability performance over time [42]. At the present state, a sustainability report can be defined as a report published by companies to report the impact of their daily activities in economic, social, and environmental terms, also highlighting the link between organizations' values, strategies, and governance models with their commitment towards sustainable development [43].

\section{Theoretical Background: Moving Towards an Integrated Approach}

The literature review shows that there are several authors who have dealt with firms' sustainability tools and practices, underlining the relevance of sustainability issues at present, both among academics and managers. Despite this, most of the literature focuses on single concepts and aspects of sustainability management practices, considering them as separate and autonomous features. In this regard, several recent studies have underlined this way of conceiving sustainability could be misleading, calling for a more integrated approach (e.g., Gond et al. [9], Battaglia et al. [10], Maas et al. [11]). In this regard, some authors have tried to propose solutions and frameworks for a more integrated view of corporate sustainability.

In particular, we conventionally identified two main streams of literature. The authors belonging to the first stream consider integration as the "overlap" of sustainability logic with traditional business strategies and/or with existing management accounting, control, and reporting systems (e.g., Adams and Frost [12], Riccaboni and Leone [13], Gond et al. [9], Giovannoni and Maraghini [14], 
Battaglia et al. [10]). In the second one, integration is conceived as the "alignment" and "interaction" of two or more business management phases (e.g., accounting, control, and reporting), tools and/or company teams, already oriented to sustainability issues (e.g., $[11,15,16])$. In a sense, it could be stated that the second perspective is an advancement of the first. In fact, at first, there is the overlap of sustainability logic to the existing management tools and practices (e.g., the sustainable dimension added to the four perspectives of balance scorecard). Then, the alignment of the "new" sustainability management dynamics can occur (e.g., sustainable balance scorecard supporting the process of sustainability reporting).

Following this division, there is a wide part of literature, positioned in the first line of research, which has empirically proposed different ways of overlapping sustainability thinking and tools with more traditional management practices. Conversely, with reference to the second research perspective, to date, an in-depth empirical analysis on how sustainability strategy, performance measurement, accounting, and control systems interplay with each other, is missing so far [11]. This constitutes an important gap in literature that needs to be filled. To the best of our knowledge, only De Villiers et al. [16] empirically developed a new model of integration of sustainability management tools, analyzing a New Zealand case study. In particular, De Villiers et al. [16] proposed a model of integration between corporate sustainability management control and reporting. Within this integration dynamics, the authors underlined the fundamental role played by stakeholders in influencing, on one hand, the choice of key performance indicators (KPIs) for both balance scorecards (BSC) and sustainability reports and, on the other hand, management focus.

The study of De Villiers et al. [16], although undoubtedly representing a starting point for the studies concerning integration (understood as alignment) between sustainability management tools, nevertheless presents only a partial view of the phenomenon. Since the integration analyzed by these authors mainly regards BSC and sustainability reports, some fundamental business functions (such as accounting and strategy) was not considered, thus leaving the aforementioned gap still underinvestigated. Maas et al. [11], conversely, proposed a more holistic framework, according to which the integration process concerns the alignment of all the company phases, from strategy definition to external reporting.

Such a framework develops around two main paths of sustainability management development, the inside-out (see Figure 1) and the outside-in (see Figure 2) perspectives, in-line with the theoretical structure proposed by Burritt \& Schaltegger [15]. In particular, the outside-in perspective argues that external stakeholders can exert considerable pressure and, consequently, have a greater impact on corporate behavior and performance, compared to internal goals and managerial commitment. Conversely, the inside-out perspective contemplates that the development of appropriate management accounting, control, and reporting systems requires a well-defined sustainability strategy and a clear definition by managers of sustainability-oriented goals and measures (11). In other words, with the inside-out perspective, the construction of accounting, control, and reporting systems is driven by the corporate sustainable strategy and commitment, while the outside-in perspective is mainly driven by the stakeholder's pressure. Finally, Burritt and Schaltegger [15] introduced a final path for the development of accounting and reporting tools: the twin track approach. Through the twin track approach, the definition of sustainability management tools is influenced both by the company's management commitment and the external pressures of stakeholder and institutions. In other words, the twin track approach is the combination of the outside-in and the inside-out perspectives. Figures 1 and 2 summarize the perspectives aforementioned.

Summarizing, the development of the accounting, control, and reporting tools for sustainability is affected by two main factors: corporate commitment and the external pressures of the institutions. Based on the degree of pressure exerted on the company (high or low), these two drivers ensure that one of the development paths (inside-out, outside-in or twin track) of sustainability management tools occurs [44]. Figure 3 summarizes the main factors which drive sustainability accounting development paths. 
Inside-out perspective:

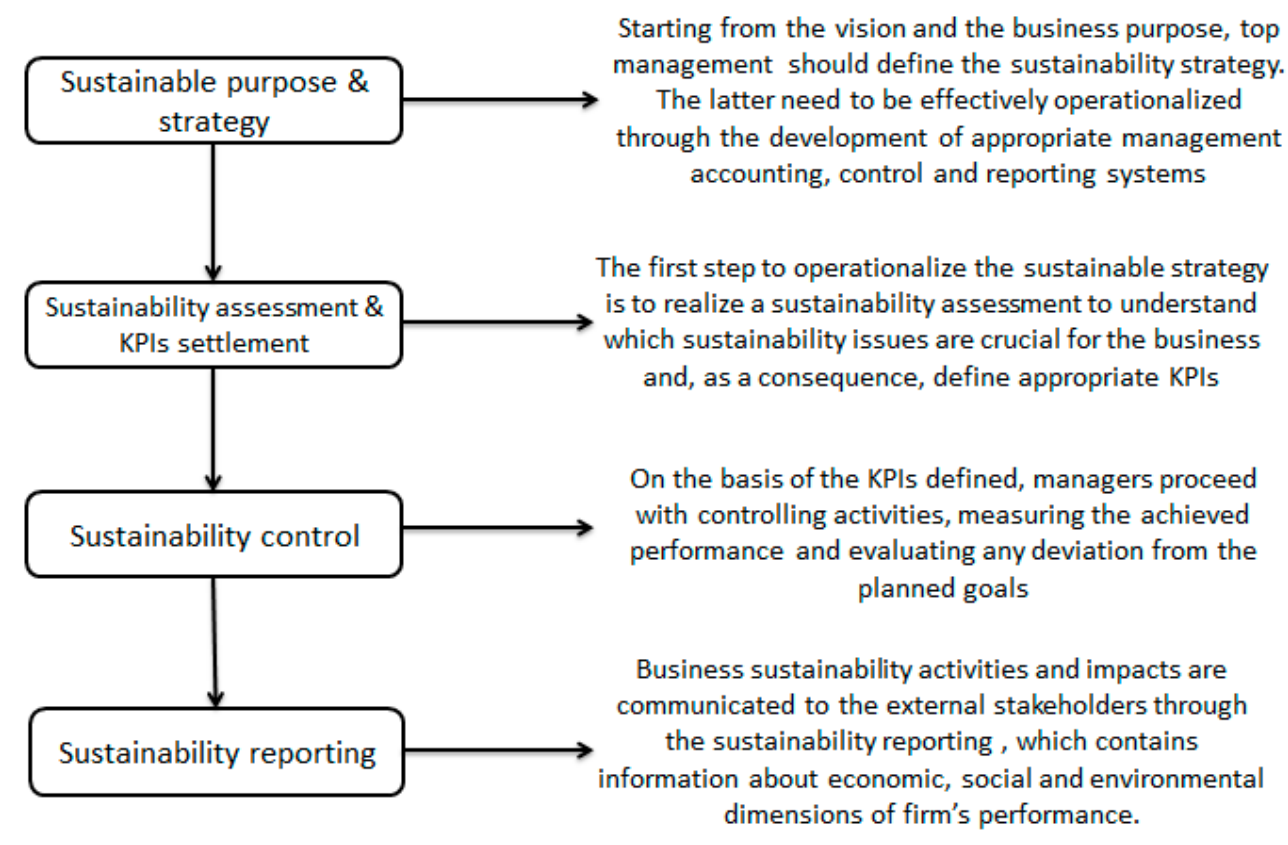

Source: Own adaptation from Burritt and Schaltegger [15] and Maas et al. [11].

Figure 1. Inside-out perspective.

\section{Outside-in perspective:}

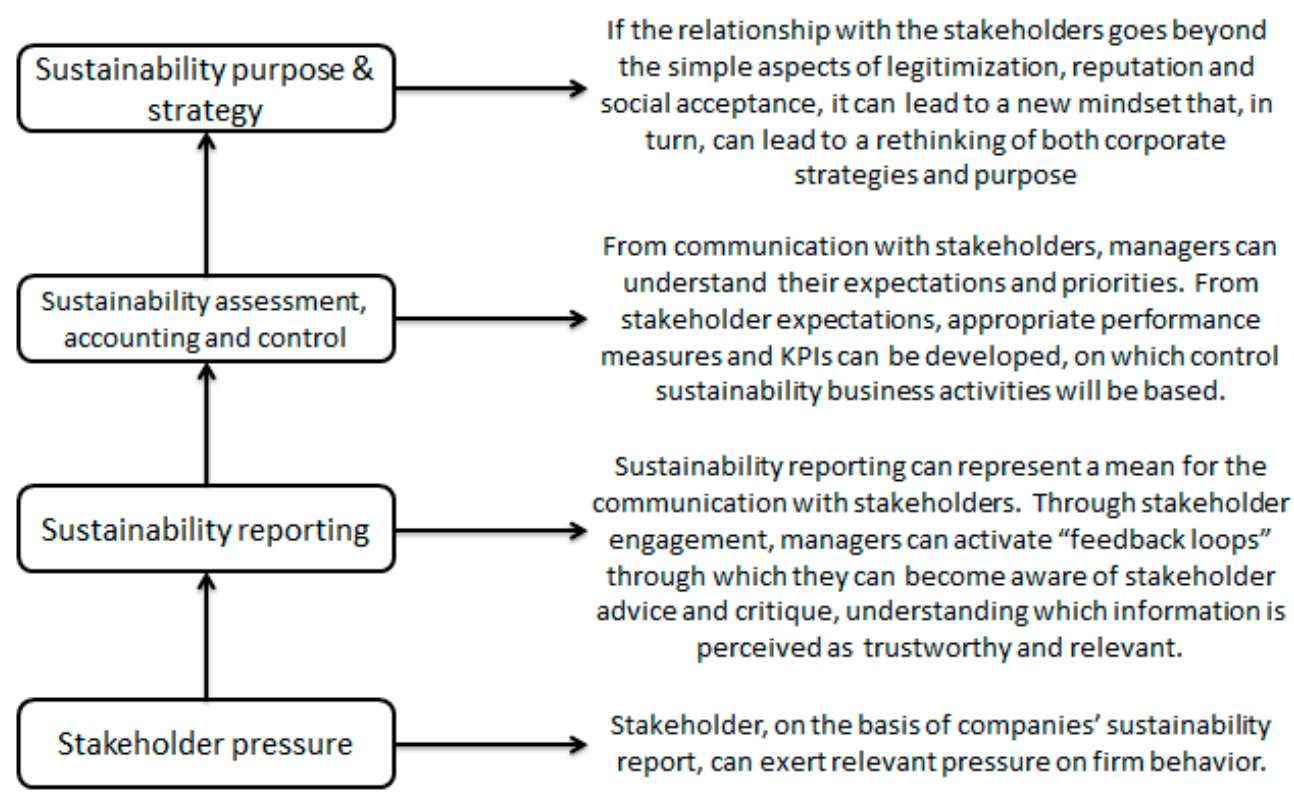

Source: Own adaptation from Burritt and Schaltegger [15] and Maas et al. [11].

Figure 2. Outside-in perspective.

In light of the theoretical constructions highlighted above, this paper aims to present a more holistic in-depth analysis on how sustainability management practices and tools interplay with each other, trying to fill the lack of this type of study in literature. In other words, this paper aims to understand, through the analysis of a case study, how the integration process, theoretically discussed 
above, concretely takes place, focusing on the human, social, and managerial dynamics that are at its base. In particular, the research goals of this study are as follows.

1. To provide empirical evidence to the theoretical framework proposed by Maas et al. [11].

2. To understand which sustainability path mainly occurs within this integration process (outside-in, inside-out or twin track).

3. To shed light on the design and alignment modalities of all the managerial tools and practices involved in the corporate sustainability management.

\begin{tabular}{|c|c|c|c|}
\hline & & \multicolumn{2}{|c|}{ Adoption pattern } \\
\hline & & $\begin{array}{l}\text { Substantive } \\
\text { (conviction in the } \\
\text { business practice) }\end{array}$ & $\begin{array}{c}\text { Symbolic } \\
\text { (no conviction in the } \\
\text { business practice) }\end{array}$ \\
\hline \multirow{2}{*}{$\begin{array}{c}\text { Institutional } \\
\text { pressure }\end{array}$} & $\begin{array}{c}\text { Weak } \\
\text { (low } \\
\text { external } \\
\text { pressure) }\end{array}$ & $\begin{array}{l}\text { INSIDE-OUT } \\
\text { (reporting results from the } \\
\text { conviction of the } \\
\text { organisation in the } \\
\text { business practice, while } \\
\text { external pressure to report } \\
\text { is low) }\end{array}$ & $\begin{array}{l}\text { ISOLATED } \\
\text { (no conviction of the } \\
\text { organisation in the } \\
\text { business practice and low } \\
\text { external pressure; the } \\
\text { organisation reports to } \\
\text { improve its image) }\end{array}$ \\
\hline & $\begin{array}{c}\text { Strong } \\
\text { (high } \\
\text { external } \\
\text { pressure) }\end{array}$ & $\begin{array}{l}\text { TWIN-TRACK } \\
\text { (reporting results from the } \\
\text { conviction of the } \\
\text { organisation in the } \\
\text { business practice as well } \\
\text { as from high external } \\
\text { pressure to report) }\end{array}$ & $\begin{array}{l}\text { OUTSIDE-IN } \\
\text { (reporting results from } \\
\text { high external pressure, } \\
\text { but the organisation does } \\
\text { not have conviction in the } \\
\text { business practice) }\end{array}$ \\
\hline
\end{tabular}

Source: Gonzalez Gonzalez and Zamora Ramírez [44].

Figure 3. Matrix of factors driving the sustainability accounting development paths.

\section{Methodology}

Given the exploratory and descriptive nature of our research, we chose the methodology of the single case study in line with Yin's [45] recommendations. The aim of this study is to highlight how and why sustainability management accounting, reporting, and control tools are adopted, designed, and aligned in a particular business context. In light of this, the case study method represents a holistic research strategy directed at understanding the internal dynamics of a single specific context [46]. This methodology, in fact, is particularly effective in deepening and richly describing the existence of a specific phenomenon [47]. Moreover, a single-case study represents a particularly valid method in studying accounting and control practices [48] because of the uniqueness and unrepeatability that distinguishes companies from each other [49].

\subsection{Selection of Case}

This paper aims to reply to Maas, Schaltegger, and Crutzen's [11] call for insights, empirically examining, through a case study, how a company implements integrated management systems, practices, and tools to tackle sustainability issues. To this purpose, we developed the analysis focusing on an Egyptian holding company, which is at the forefront of fostering sustainable development, also taking part in several public-private international and regional initiatives currently implemented. We selected such a firm, firstly because it operates in a developing country and because in spite of 
political, socioeconomic, and environmental contingent hardships, it succeeds in operationalizing sustainability principles at the management level. Secondly, because we intended to examine the background processes of such a firm, following findings of previous studies focused on corporate performance, which identified it as one of the most influential social enterprises [17-20] and a virtuous example of a sustainable corporate practitioner [21]. Finally, we chose this firm because we considered it one of the best innovators due to its inclusion in a new database of a Mediterranean corporate sustainable observatory developed by the PRIMA Programme.

Such a feature makes this case study of great interest both for the academic community and for the business world as it shows an optimal practical synthesis of how the sustainable management of a business can guarantee the sustainable development of an entire community.

\subsection{Data Collection and Analysis}

Following Yin's [45] study, we ensured our study was rigorous by applying data triangulation. In particular, data collection and analysis processes were carried out in several steps.

In a first phase, we verified that the company's accounting activities and tools were compatible with the objectives of our study. For this purpose, we consulted the company website and the company reports present in it. Once the potential of the case was ascertained, we requested, via email, to obtain internal documents, such as PowerPoint presentations, performance indicators, and various accounting documents, so as to verify the presence of a real integrated management accounting and control approach. Finally, the accounting documents collected were carefully analyzed, and the related contents were corroborated through face-to-face interviews with company managers, using software such as Skype and Zoom.

The entire process of selection, collection, and analysis of data lasted from September 2018 to January 2019, incorporating a period of approximately five months. In order to have multiple sources of data and corroborate the document contents, we interacted in different ways with business managers. In particular, two Skype meetings were held for about two hours with the chief sustainable development officer and a member of the research and international affairs of Heliopolis University (partner of SEKEM initiative). In addition to these meetings, further information on the data received was requested through the exchange of numerous emails throughout the investigation period. The interactions with managers with different backgrounds were fundamental, as they allowed us to carry out a more holistic investigation, since we had different points of view of the phenomenon being studied.

Finally, the combination of the various documentary sources and the statements of the managers allowed us to reconstruct the internal dynamics that occur in the processes of employment and alignment of the various sustainable management accounting and control tools.

\section{Case Study}

\subsection{Business Background}

SEKEM is an Egyptian enterprise, employing 1290 workers, founded by Dr. Ibrahim Abouleish in the Egyptian desert in 1977, with the aim to achieve the sustainable development of the Egyptian community through long-term economic-, social-, cultural-, and ecological-oriented activities. In order to tackle the major Egyptian problems of food security, water scarcity, climate change, and widespread poverty, the main competitive solutions adopted by SEKEM are the transition towards organic/biodynamic agriculture and the production of sustainable phytopharmaceuticals as well as of organic textiles and clothes. According to its business values and activities, during the years, SEKEM developed a remarkable holistic business model, in accordance with ecological and ethical principles, characterized by four pillars: economic life, ecology, societal life, and cultural life. In-line with this business model structure, part of the profits from economic activities is reinvested in the other sustainable initiatives, also in association with long-standing international partnerships. In Europe, 
in fact, there are five associations, in five different countries (Austria, Germany, the Netherlands, Scandinavia, and Switzerland), which support cultural work for the SEKEM Initiative through funding and donations. Together with its European partners, SEKEM founded the International Association for Partnership in Ecology and Trade (IAP), with the aim of facilitating interaction and communication between farmers, producers, and traders, also improving the quality of organic food. In this way, SEKEM operates as a bridge between countries to the North and South of the Mediterranean area, to promote the purpose of SEKEM and encourage an intercultural dialogue.

From a social perspective, $10 \%$ of profits of SEKEM companies cofinance cultural and social activities of the SEKEM Development Foundation, a private nonprofit organization, with the aim to improve healthcare and educational systems and manage training centers. Additionally, in 2012, the Heliopolis University for Sustainable Development was established under the umbrella of SEKEM Initiatives, underlining the original idea of Dr. Ibrahim Abouleish, which is the achievement of sustainable development by reinvesting in the community. Figure 4 reports the business model of SEKEM holding.

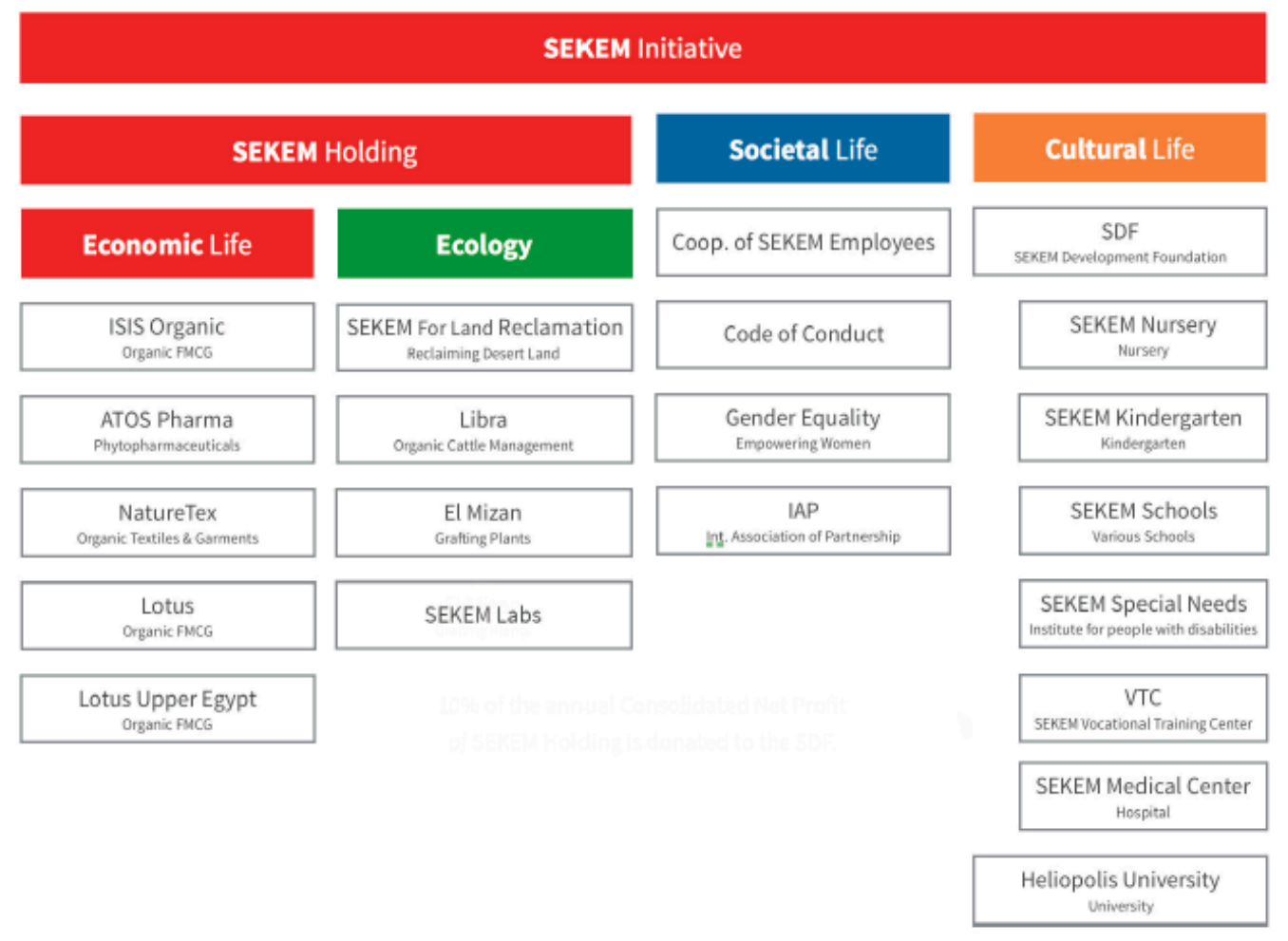

Source: SEKEM internal documents.

Figure 4. SEKEM business model.

\subsection{The SEKEM Purpose and Strategy}

"The strong vision of the founder of sustainable development has become part of the company's DNA and represents the philosophy without which SEKEM could not exist."

(SEKEM scholar affiliated)

Starting from the words of a PhD scholar of the Research and International Affairs of Heliopolis University, it is clear how the strong vision of the founder guides the core company's values and actions and has become a reality in what is now the purpose of SEKEM:

"Sustainable development towards a future where every human being can unfold his individual potential; where mankind lives together in social forms reflecting human dignity; and where all economic activity is conducted in accordance with ecological and ethical principles." 
From such a purpose derives the SEKEM strategy of reclaiming the desert lands and cultivating them in a sustainable way, mitigating the main Egyptian issues of food insecurity, water scarcity, and climate change, also developing a sustainable human community.

Managerial commitment was essential to the launch and development of SEKEM initiatives in a context like the Egyptian one, where attention towards sustainability issues by external policy-makers and stakeholders (understood as physical entities, not as environmental or social issues) is relatively weak. In line with this, regarding the actors/factors that pushed SEKEM to pursue sustainability goals and activities, the Chief Sustainable Development (SD) Officer states, "It's not about policy-makers. Policy-makers and institutions around us are pretty much on the opposite respect to our philosophy." As proof of this, he confirms that the main shareholders are European ethical banks, while there are no Egyptian banks, which demonstrates that they are "not very interested in such a long-term sustainable approach." In-line with this, the impulse to pursue a purpose of sustainable human development comes almost exclusively from company commitment, as stated by the Chief SD Officer "we are driven mainly by our vision, by our connection to the SEKEM philosophical principles that guide us and that drive our leadership and our community."

The sustainable purpose of SEKEM has had a fundamental operational impact, guiding actions at all business levels. In fact, at the operational level, the corporate purpose is translated into four fields of life, on which the organizational structure of SEKEM is based: economic life, ecology, societal life, and cultural life. This organizational structure provides that for each field of life different companies, institutions, and NGOs operate, which pursue the corporate purpose of SEKEM of establishing a community in Egypt oriented to long-term economic, environmental, and social development. For this reason, the Chief SD Officer describes the structure of SEKEM as "holonic", as it is understood as a group business model made up of different interactive organizations, each with its own goals, tasks, and responsibilities, giving their contributions to the realization of the general purpose of SEKEM. The four pillars that characterize the SEKEM business model and, consequently, the operational company's activities, have been translated, since 2008, in a specific accounting framework named Sustainability Flower (cf. Figure 5). This framework represents, today, the main baseline tool for business management, performance assessment, and corporate communication, guiding everyday company strategy operationalization.

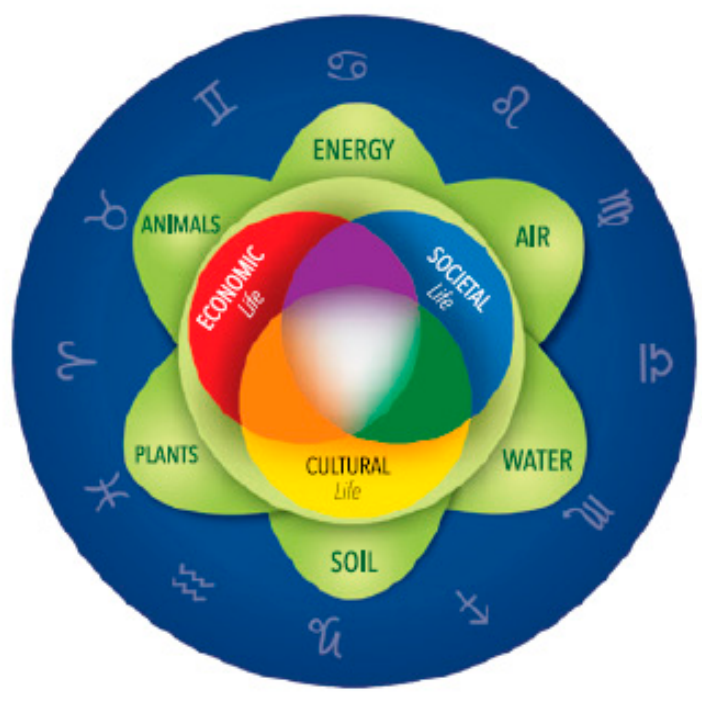

Source: SEKEM documents

Figure 5. The Sustainability Flower and the four fields of life (economic life; ecology with its six subdimensions; societal life; and cultural life). 


\subsection{SEKEM Sustainability Accounting: From Strategy to KPI Settlement}

What has been described up until now represents the cultural base on which SEKEM has built its entire business reality. In-line with the pillars that characterize the company strategy and business model, accounting tools and the related key performance indicators (KPIs) have been developed.

The accounting frame, in fact, follows the Sustainability Flower structure. In particular, considering the four sustainability pillars, the company managers have defined eighteen mediumand long-term vision goals. The latter are then operationally translated into an accounting statement, in which each vision goal is associated with more short-term objectives (current and next year) to be pursued, as well as the related KPIs for the evaluation of the achieved results.

Given the complexity of the SEKEM business model, the accounting structure was set up to holistically comprehend all aspects and entities involved in the "'SEKEM Initiative". SEKEM Holding has a consolidated accounting statement in which the various vision goals, divided according to the pillar to which they refer, are associated with the concerned UN Sustainable Development Goals (SDGs), as well as with the projects carried out for their pursuit. The latter are complemented by KPIs to be considered in order to quantify their progress. Each project, with the related KPIs, is assigned to the different entities that make up SEKEM initiatives, based on their role in the various sustainability pillars and their specific background. Finally, the accounting framework outlines for each entity, the intermediate objectives to be reached in the short term and the managers responsible for the assigned activities (Figure 6).

\begin{tabular}{|c|c|c|c|c|c|c|c|c|c|c|}
\hline Flower & SDGs & Egypt Vision 2057 & SEKEM Goals 2027 & Projects & Priority & Entity & Key Indicator & Objective for 2019 & Beyond 2019 & Manager \\
\hline $\begin{array}{l}\text { Ecological } \\
\text { Life }\end{array}$ & SDG 12 & $\begin{array}{l}\text { Egypt is a national } \\
\text { role model in reducing } \\
\text { waste production and } \\
\text { in optimization of }\end{array}$ & $\begin{array}{l}\text { SEKEM is a waste-free community and } \\
\text { disseminated the zero waste management } \\
\text { concept in Egypt together with HU. }\end{array}$ & $\begin{array}{l}\text { Waste amount by the companies } \\
\text { fully monitored. }\end{array}$ & A & \begin{tabular}{|l|} 
all Sekem \\
entities
\end{tabular} & \begin{tabular}{l|} 
amount of \\
waste in $\mathrm{kg}$
\end{tabular} & & & \\
\hline $\begin{array}{l}\text { Ecological } \\
\text { Life }\end{array}$ & & \begin{tabular}{|l|} 
Egypt is a national \\
role model in reducing \\
waste production and \\
in optimization of
\end{tabular} & $\begin{array}{l}\text { SEKEM is a waste-free community and } \\
\text { disseminated the zero waste management } \\
\text { concept in Egypt together with HU. }\end{array}$ & $\begin{array}{l}\text { Waste management training } \\
\text { provided. }\end{array}$ & A & $\begin{array}{l}\text { ISIS, Sekem, } \\
\text { Companies }\end{array}$ & $\begin{array}{l}\text { number of } \\
\text { trainings }\end{array}$ & & & \\
\hline $\begin{array}{l}\text { Ecological } \\
\text { Life }\end{array}$ & & $\begin{array}{l}\text { Egypt is a national } \\
\text { role model in reducing } \\
\text { waste production and } \\
\text { in optimization of }\end{array}$ & $\begin{array}{l}\text { SEKEM is a waste-free community and } \\
\text { disseminated the zero waste management } \\
\text { concept in Egypt together with HU. }\end{array}$ & Use waste in fine arts & A & $\begin{array}{l}\text { HU, CESD } \\
\text { Core Program }\end{array}$ & $\begin{array}{l}\text { kg of waste } \\
\text { used }\end{array}$ & & & \\
\hline $\begin{array}{l}\text { Ecological } \\
\text { Life }\end{array}$ & & \begin{tabular}{|l|} 
Egypt is a national \\
role model in reducing \\
waste production and \\
in optimization of
\end{tabular} & $\begin{array}{l}\text { SEKEM is a waste-free community and } \\
\text { disseminated the zero waste management } \\
\text { concept in Egypt together with HU. }\end{array}$ & $\begin{array}{l}\text { Better waste collection with } \\
\text { economic incentives. }\end{array}$ & A & \begin{tabular}{|l} 
HU, CESD \\
Busines
\end{tabular} & $\begin{array}{l}\text { number of } \\
\text { economic } \\
\text { incentives }\end{array}$ & & & \\
\hline
\end{tabular}

Source: SEKEM internal documents.

Figure 6. Extract from the SEKEM accounting model.

Each entity, in turn, records its own achieved results and periodically communicates them to the holding company so that it can integrate the individual accounting records in the consolidated statement.

The constructing process of this accounting model started in 2008, in line with the creation of the Sustainability Flower framework. Starting from this general framework, through a kind of materiality analysis, top managers identified the sustainability main issues and, consequently, the related accounting metrics. In particular, SEKEM's management has defined a well-structured set of KPIs and targets. The definition of this corporate integrated performance measurement matrix has been the result of a crucial internal auditing process in which the management "has translated the framework of Sustainability Flower into indicators... the set of those sustainability KPIs is definitely an outcome of a kind of materiality analysis," as stated by the Chief SD Officer. SEKEM's accounting system has, thus, been built on the principles characterizing the corporate purpose and strategy, as well considering those targets highlighted in the Agenda2030 SDGs framework. Considering such an integrated approach, SEKEM Chief SD Officer claimed "All KPIs belong to aspects, and all the aspects belong to the four dimensions of sustainable development which form the DNA of our initiatives. 
That's the link!" In fact, for each pillar, several issues are identified. Moreover, the KPIs matrix tool aligns one or more SDGs for every issue. Each of these issues is assessed through a specific KPI, which allows them to evaluate the performance achieved compared to a preestablished target value (for more details, see SEKEM's sustainability KPI matrix reported in Table A1).

The use of such an integrated accounting system allows SEKEM managers to measure and systematically monitor corporate economic, environmental, social, and cultural performance. Moreover, it allows them to identify and correct possible misalignments from targets and support efficiently the internal and external reporting processes.

\subsection{SEKEM Sustainable Management Control: From Accounting to Balance Scorecard (BSC)}

In the literature, the concepts of accounting and control are often linked, since accounting represents the information base through which the business control unit carries out its monitoring and benchmarking activities. In SEKEM, such a link is given by the deep connection between the accounting model and the performance balance scorecard. Starting from the aspects and KPIs identified within the accounting statement, the management of SEKEM has elaborated a sustainable balance scorecard through which it provides a quick impression of where the company stands in terms of its sustainability performance. In particular, two kinds of scorecards have been implemented. One of them highlights the type of impact that SEKEM activities produce on the several aspects characterizing the four flower pillars (no impact, negative impact, or positive impact); the other, instead, quantifies those impacts through KPIs. In the first balance scorecard, each sustainability flower pillar is divided in a plurality of "performance aspects". The latter can be defined as a subset of the flower sustainability pillars, which comprehend all the projects that address the issues to which the performance aspect refers (for example, a water recovery project comes in the performance aspect named "water use", which, in turn, is part of the water pillar of the ecological life dimension). For each performance aspect, the balance scorecard presents a set of goals that need to be pursued, which in turn are flanked by the operational levers on which to act for their achievement. Finally, the impacts produced by SEKEM activities on the different performance aspects are assessed through a traffic light indicator, where green shows an excellent performance, red means no action or negative impact, while yellow indicates that actions have been carried out because awareness exists (for more details, see the SEKEM qualitative sustainability balance scorecard reported in Figure A1).

This first balance scorecard has a more qualitative approach and has the function of giving a quick feedback on the impact of SEKEM's activities on the sustainability flower dimensions.

With the aim of giving a quantitative dimension to the impacts highlighted in the first scorecard, a second and more numerical balance scorecard has been realized. This second scorecard starts from performance aspects derived from sustainability pillars but, instead of the present goals and levers, highlights specific KPIs, associated to which are numeric targets to be pursued and the results achieved. Finally, a visual results evaluation through a five-point scale (from not achieved to totally achieved) is introduced (cf. Figure 7).

This articulation of the balance scorecard and performance measurement has a dual function, for management decision-making support and for both internal and external communication. The balance scorecard system allows managers to extract priority information to communicate to the CEO as well as represents the base from which relevant information is disclosed to be communicated to external stakeholders through sustainability reporting.

What has been described so far regarding the performance measurement structure represents the most tangible dimension of the management control, since it is related to the material tools used in monitoring and benchmarking activities. In addition to the tangible dimension of control, there is also an intangible dimension, which is more related to human interactions and activities.

The complexity of the SEKEM business reality means that the concrete accounting and monitoring of the overall sustainability performance can only occur through a constant dialogue between all the managers and entities that are part of the SEKEM initiative. Depending on the company management 
field (strategic, operational, cultural, etc.), periodic meetings are organized, in which the progress or possible future developments of the business are discussed at various company levels. In these meetings, the key means of communication are represented by accounting data and sustainable KPIs, demonstrating how the two dimensions of control are preliminary to one another in the process of monitoring and evaluating sustainable performance. Table 1 shows the types of meetings as well as the actors involved, and the managerial tools used.

\begin{tabular}{|c|c|c|c|c|c|c|c|}
\hline Aspect & Indlcator & Unit & Target & 2017 & 2016 & $\begin{array}{l}\text { Evalua- } \\
\text { tion }\end{array}$ & Comment \\
\hline Land Use & $\begin{array}{l}\text { Size of total land } \\
\text { reclaimed }\end{array}$ & feddan & 1,628 & 1,628 & 1,628 & & \\
\hline Compost & $\begin{array}{l}\text { Total amount of } \\
\text { compost produced }\end{array}$ & tons & 2,000 & 1,982 & 2,250 & & $\begin{array}{l}\text { Reduction in cultivated area at SEKEM } \\
\text { farms }\end{array}$ \\
\hline Seeds & $\begin{array}{l}\text { Share of seeds } \\
\text { used by SLR from } \\
\text { own production }\end{array}$ & $\%$ & 100 & 85 & 80 & & \\
\hline Seeds & $\begin{array}{l}\text { Number of seed } \\
\text { varieties in own } \\
\text { seed bank }\end{array}$ & Number & 344 & 344 & 330 & & \\
\hline Seeds & $\begin{array}{l}\text { Share of used } \\
\text { seeds that are } \\
\text { organic and un- } \\
\text { treated }\end{array}$ & $\%$ & $100 \%$ & $85 \%$ & $100 \%$ & & \\
\hline Animal Husbandry & $\begin{array}{l}\text { Total number of } \\
\text { Bulls }\end{array}$ & Number & 45 & 39 & 29 & & \\
\hline
\end{tabular}

Source: SEKEM Sustainability Report.

Figure 7. Extract from SEKEM quantitative sustainability balance scorecard.

Table 1. SEKEM management meetings.

\begin{tabular}{|c|c|c|c|}
\hline Frequency of Meeting & Actors & Content of Meeting & Type of Documents Shared \\
\hline Weekly meetings & $\begin{array}{l}\text { - } \text { CEO } \\
\text { Employees and broader SEKEM } \\
\text { community (including farmers } \\
\text { and university's staff) }\end{array}$ & $\begin{array}{l}\text { Discussion, on a philosophical but also } \\
\text { practical level, what the purpose of } \\
\text { SEKEM means, with the aim to collect } \\
\text { some ideas and translate the purpose } \\
\text { into concrete solutions and projects } \\
\text { (vision meetings) }\end{array}$ & $\begin{array}{ll}\text { - } & \text { Sustainability } \\
& \text { Flower framework }\end{array}$ \\
\hline Monthly meetings & $\begin{array}{l}\text { - Each company General Manager } \\
\text { - Team of Functional Departments } \\
\text { - SD Committee }\end{array}$ & $\begin{array}{l}\text { Presentation and discussion of } \\
\text { consolidated sustainability data with all } \\
\text { companies' groups }\end{array}$ & $\begin{array}{l}\text { - } \text { Management Reports } \\
\text { - Sustainable KPIs }\end{array}$ \\
\hline Quarterly meetings & $\begin{array}{l}\text { - CEO } \\
\text { Quarterly Board Committee } \\
\text { (composed of members of SD } \\
\text { Committee and other } \\
\text { nonexecutive Board members } \\
\text { with experience in the field of } \\
\text { sustainable development) }\end{array}$ & $\begin{array}{l}\text { Discussion and validation of data about } \\
\text { sustainable performance of } \\
\text { SEKEM group }\end{array}$ & $\begin{array}{l}\text { - Sustainable KPIs } \\
\text { - Balance Scorecard }\end{array}$ \\
\hline Annual meetings & $\begin{array}{l}\text { - Board of directors } \\
\text { - CEO }\end{array}$ & $\begin{array}{l}\text { Discussion and approval of } \\
\text { Sustainability Report }\end{array}$ & - Sustainability Report \\
\hline
\end{tabular}

Source: Authors' elaboration.

On the communication and control function held by the management meetings, the Chief SD Officer states "we collect management report and data of each SEKEM entity, and discuss them 
in monthly meetings with each company managers and functional departments... the same occur for SEKEM holding, where we discuss with top management, and that's how we communicate... Every three months there is a meeting between CEO and Quarterly Board Committee in which consolidated sustainable performance data are discussed and validated... In half year base meetings are discussed financial indicators and a prioritize set of sustainable indicators to have a look on general business performance."

\subsection{SEKEM Sustainability Reporting: From BSC to Sustainability Report}

After setting goals, targets, and KPIs and measuring and evaluating performance according to the Sustainability Flower framework, the reporting phase takes place through the preparation of the Sustainability Report (SR). This document presents the evaluation and communication of SEKEM's performance through the quantitative Balance Scorecard, structuring the analysis according to the four fields of life. In particular, for each of them, starting from the performance aspects of the Sustainability Flower framework, some aspects have been removed or added according to stakeholders' demand or the management's decision. In correspondence to every aspect, various indicators are analyzed, specifying for each of them the unit of measurement, the target to reach, and the performance actually achieved, compared to that of the previous year. In the penultimate column, the degree of success in reaching the preestablished target is graphically represented, on a scale between 1 and 5 (Figure 8).
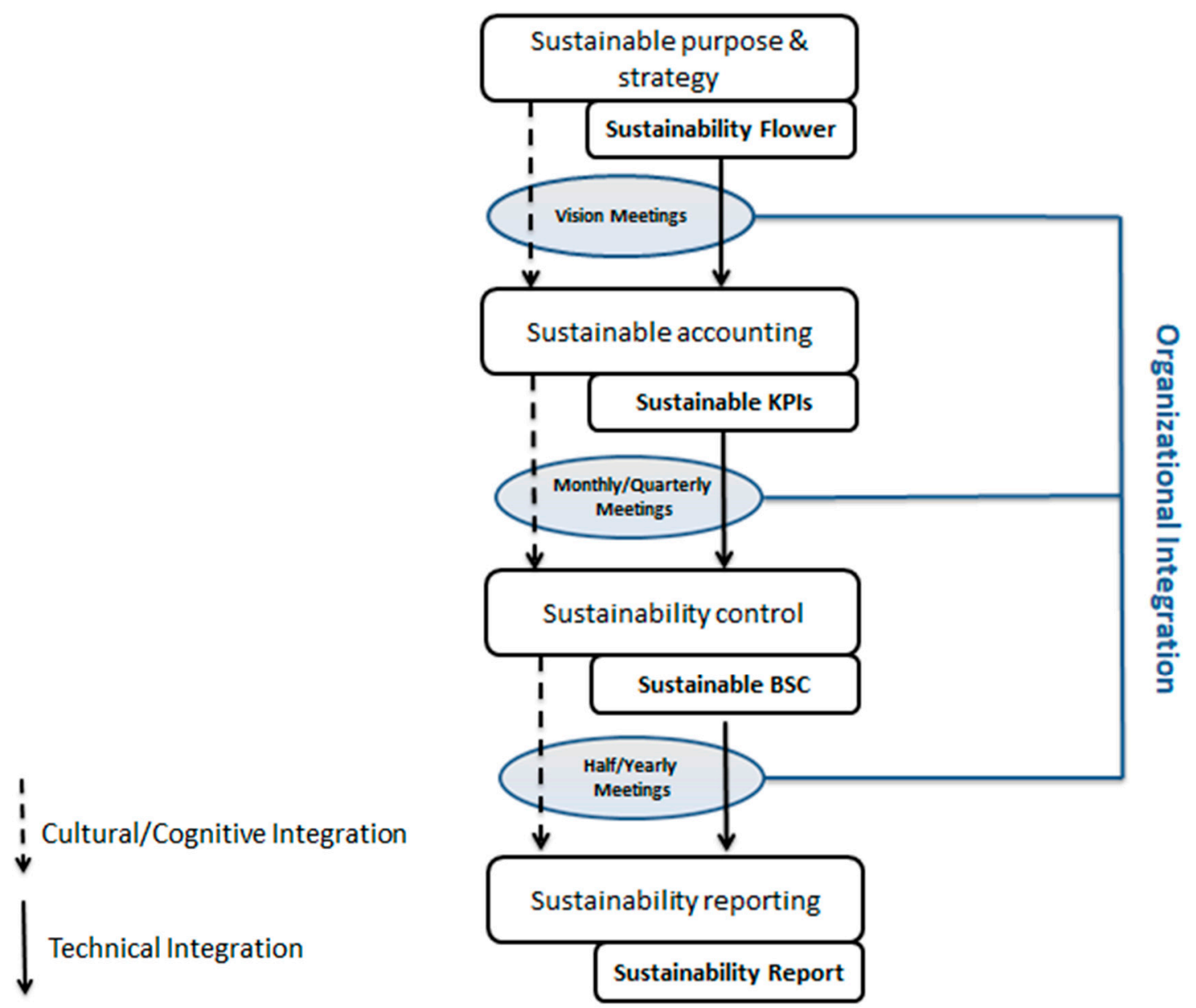

Source: Authors' elaboration.

Figure 8. SEKEM inside-out integration dynamics.

Regarding the choice of the main aspects to be included in the SR, the Chief SD Officer states that "We meet some of our key partners and we try to match what is most important for us with what is 
important for them, with the aim of establishing the relative priorities... and to become a little bit more focused on our goals." The stakeholders' requests are collected and taken into consideration in order to establish which indicators, among those defined by the top management, must be included in the report. The SR, thus defined, is perfectly aligned with the company's purpose and medium/long-term goals, presenting a holistic and integrated performance assessment of the four fields of life, on which the organizational structure of the company is based. In conclusion, the SR represents the final step that summarizes the vertical integration process (between company purpose, performance measurement, control systems, and reporting) and the horizontal one (between the four dimensions of sustainability).

\subsection{SEKEM Management Integration Path: Why and How}

The management tools and practices examined so far, as well as the culture to the constant monitoring of sustainability performance in all its dimensions, make SEKEM a social innovator able to support the sustainable growth and development not only of the business itself, but also of an entire community.

The steady attention to social and environmental criticalities of the Egyptian context, together with the strong managerial commitment, ensure that sustainability issues are perfectly integrated in the company strategy and, consequently, in management practices and tools.

Since Egypt (in coherence with other countries of the Southern shore of the Mediterranean) presents numerous problems related to land reclamation, water scarcity, and food security, a long-term management approach is necessary in order to preserve the environmental production factors. This is the basic idea that characterizes the SEKEM philosophy. Thus, the Chief SD Officer says: "Imagine if you start working in the desert, you need very patience and long-term capital with not high interests. From a capitalistic perspective it is not really profitable... it makes sense in a true cost perspective or including social and environmental benefits." The SEKEM philosophy is linked with the true cost accounting approach, according to which the negative impacts that the company produces on society and the environment must be considered and accounted as costs, and the positive impacts are comparable to revenues. The SEKEM philosophy derives from the ideas and values of the founder and his family, who still today drive SEKEM's leadership and management.

However, such a sustainable business approach is not always shared within the context of reference. Institutions and policy-makers, in fact, tend to be little inclined to issues of sustainable development and to exert a rather weak pressure on companies about sustainability practices. In this regard, the Chief SD Officer state: "Policy-makers and institutions around us are pretty much on the opposite respect to our philosophy...there is a lot of market distortion that prevent us from seeing the true costs of what we do."

These statements allowed us to understand that the development and subsequent integration of sustainable management accounting, control, and reporting tools have mostly depended on the conviction of top management in those sustainability management practices in a context of weak stakeholder pressure, configuring an inside-out path of adoption (see Figure 3). Such a managerial adoption path has been confirmed by the sustainability accountant who, in this regard, affirms "No pressure changed our accounting models... We have been always in the lead, on the forefront of our accounting, control and reporting system."

The empirical evidence presented so far confirms the theoretical validity of the Gonzalez Gonzalez and Zamora Ramírez [44] matrix. We have verified, in fact, that in contexts with weak stakeholder pressures, the development of the accounting and control tools derives from the culture and the conviction of the company top management, in a top-down or inside-out approach. Moreover, the Burritt and Schaltegger [15] and Maas et al. [11] framework has also been empirically validated. The integration process of the various accounting tools took place through several steps, in which each previous tool represented the development basis for the next. Starting from the company purpose, the Sustainability Flower framework was developed. Within this framework, the guiding principles that drive the company strategy and actions were formalized, and the accounting model and the related 
indicators were developed. The accounting frame, in turn, represents the information base of the SEKEM sustainable balance scorecard through which management control activities are carried out. Finally, the priority KPIs present in the balance scorecard constitute the key information included in the sustainability report and, therefore, communicated to external stakeholders.

The integration of accounting, control, and reporting tools can be classified as the most technical and superficial part of the whole alignment process. Alone, however, it is not enough to fully explain how managerial integration takes place. To this end, it is necessary to highlight that the integration of the tools was possible thanks to a further alignment of the various corporate actors and departments and a strong and extensive sharing of the same business culture.

This subdivision conceptually reflects the three integration dimensions identified by Gond et al. [9]: technical, organizational, and cognitive. However, these last are reinterpreted considering the results of this business case. In their study, Gond et al. [9] intended for these forms of integration to be used as an overlap between the traditional business practices and those of sustainability. The authors, focusing on the integration between traditional control systems and sustainable ones based on their level of integration on the three dimensions, delineated eight ideal types of organizational configurations: from the lowest and decoupled scheme (configuration $\mathrm{A}$ ) to the highest sustainability integrated ones (configuration $\mathrm{H}$ ).

In such a framework, SEKEM can be placed in the " $\mathrm{H}$ " configuration, since it represents a business reality in which sustainability, strategy, and decision-making processes are completely overlapping, and the accounting and control structure holistically accounts for all sustainability aspects. For this reason, in the present study, it makes more sense to reinterpret the three Gond et al. [9] dimensions of integration as alignment modalities (rather than overlapping) within the adoption path frame proposed by Burritt and Schaltegger [15].

In light of this, the organizational integration is complementary to technical integration, since the SEKEM group includes several entities, each of which belongs to a different pillar and with different projects to be carried out. In this context, the dialogue between the sustainability department, responsible for aggregating and consolidating data at group level, and general managers of the various business units, becomes crucial and represents the main form of integration. This dialogue takes place through periodic meetings in which problems, future actions, possible strategy adjustments or metrics definitions are discussed, through the accounting systems and the sustainability performance data. In this process of interaction between managers, the accounting and control tools rediscover their communication function, encouraging dialogue between the different company levels and at different company management phases (account, control, or reporting). At the same time, the continuous dialogue led to a learning-by-doing process, through which performance metrics and accounting and reporting systems were gradually customized, based on the priorities and needs expressed by the managers and departments involved in the interaction and integration process. Regarding the integration topics presented above, SEKEM key respondents state

"we [referred to SD holding department] work with the management of each company level, as well as with the holding top management... We share the holistic reporting and management system information within management meetings, in order to discuss and improve measures and to relate them back to our long-term vision...This is our means for an effective integration and for building a shared vision...we continuously learn and continuously try to adapt the flower (and the related indicators and metrics) to the new aspects that come into play."

The last aspect of integration is the cultural/cognitive one. From the empirical evidence that emerged from the case, we can state that the technical and organizational integration that took place in SEKEM would hardly have been successful without aligning all company actors' culture with the sustainable SEKEM purpose. Dialogue and mutual understanding, which are required at different stages of business integration, can only take place when everyone shares the same values and objectives. The process of disseminating corporate values was fundamental in order to align all company levels with a single purpose: the pursuit of the long-term sustainable objectives of SEKEM. 
"Align organization to our purpose really means to raise the awareness of our employees and of our leaders... It's all about consciousness level... not all trust the holistic idea, not everyone can relate to all the SEKEM vision goals and the main challenge is to provide everyone with an understanding of how they relate to the SEKEM vision goals... this is important because, of course, this vision goals must be achieved by joint effort of all entities under the SEKEM umbrella and that require a quite integrated thinking..." In this perspective, the Sustainability Flower framework is the main means of communication and dissemination of the SEKEM purpose and vision. It plays the role of a reference point in the various meetings that top management performs to instruct people to those guiding principles, and it drives the daily actions of anyone working in SEKEM. The cultural aspect becomes the background in which all the other business alignment and interaction dynamics take place. Regarding this, the key business respondents confirmed

"The spread of SEKEM purpose to the different employees and middle-management level, occur by regular vision meetings... Helmy Abouleish, the CEO and the cofounder of SEKEM, periodically meets different employees' groups in order to discuss, on a philosophical but also practical level, what the SEKEM philosophy means... we [referred to SEKEM holding managers] support people in understanding what does SEKEM vision goals mean to them, what is their role, what do we expect from them, by couching, by training and by ongoing discussion in which the focus is not only on financial-economic aspects and data, but also on cultural, society, and ecological data and dimensions... Dialogue is the most important integration means!"

In light of the business dynamics analyzed, we can conclude that the technical perspective is only the most superficial aspect of the entire integration process, which is much more complex and also includes the most intangible and intimate company aspects, such as the human and social ones.

Indeed, the case study showed that technical integration is possible only when the organizational and cultural integrations are also fully verified. The complete and holistic interplay of these three integration dimensions allows the effective operationalization of the business sustainable purpose and strategy through the different management tools and phases, in the modalities foreseen by the Burritt and Schaltegger [15] and Maas et al. [11] framework (Figure 8). Finally, the alignment process, discussed above, enabled SEKEM managers to translate long-term objectives into shorter-term objectives and operational activities, as well as to continuously monitor the results achieved. On the basis of accounting information, the management decides about future activities and priorities to be addressed with greater urgency in order to preserve the socioenvironmental context.

\section{Conclusions}

Nowadays, with the launch of Agenda 2030 [1], firms are contingently called to face sustainability issues at the management level fostering a resilient economic growth and taking in account stakeholder expectations. Management practices and commitment can play a crucial role in making sustainable business purpose and strategy operational. Nevertheless, the isolated adoption of sustainability-oriented management tools can lead to only symbolic behaviors, with no concrete effects on business sustainability impacts. To this end, a strong integration between all sustainable management practices and tools is required.

Hitherto, only few papers have dealt with such type of integration, leaving open research gaps regarding the related modalities of interaction between different sustainable business practices.

From this perspective, Maas et al. [11], starting from the Burritt and Schaltegger [15] study, proposed a theoretical model of integration of sustainability-oriented management tools (from strategy to reporting). The authors, moreover, underlined that an in-depth empirical analysis on how such managerial tools interplay with each other is missing so far. Taking this gap as a starting point, this paper developed a business case study in which we analyzed the integration dynamics that occur within the sustainability mechanisms of an Egyptian firm. Since the object of this study concerned sustainability issues, we intentionally chose a company that operates in a context in which these 
issues are fundamental for the region's growth and development. In Egypt (as in the other countries of the Southern shore of the Mediterranean), problems like water scarcity, land reclamation, and poverty are on the agenda and need to be addressed. SEKEM has included these critical aspects within its purpose and strategy, trying to match business sustainable development with that of the entire Egyptian community. To this end, sustainability-oriented management tools play a fundamental role in supporting managers in the daily operationalization of the strategy as well as in monitoring to ensure that long-term sustainable objectives are constantly pursued. Nevertheless, what makes SEKEM's management system effective is a strong integration between the different phases that lead to the strategy being implemented, and the related results to be accounted for, monitored, and, finally, communicated.

The results of our qualitative analysis allow us to rethink the concept of integration commonly used in literature when scholars debate about sustainability management issues at the firm level. In line of this, we demonstrated that the integration concept is not only about management tools, but it also involves, in a more holistic perspective, organizational and cognitive factors. The technical integration of management tools can only occur when all organization levels are well aligned, and everyone shares a common set of values. These findings represent the principal aspect of the value added delivered by this study to the domain.

Moreover, this paper offers further important theoretical insights. First, the Maas et al. [11] framework was empirically validated and, additionally, enriched with more business dynamics that underlie the physical integration of management accounting, control, and reporting tools. Moreover, we confirmed that in the context of weak stakeholder pressure for sustainability practice adoption, the design and integration modalities of sustainable management tools derive from managerial commitment in a top-down perspective. Ultimately, the case study evidence highlights the importance of shifting the concept of integration from "overlap" of traditional management tools with sustainability-oriented ones, to "alignment" of different sustainable management tools and practices. In this sense, we have readapted the three types of integration (technical, organizational, and cognitive) proposed by Gond et al. [9] in such a way that these dimensions result as forms of alignment of the different phases of the sustainable business management, rather than as an overlap between traditional and sustainability-oriented managerial mechanisms.

Starting from the previous theoretical considerations, the SEKEM case study also presents several managerial pieces of evidence, which are useful in developing an effective managerial system to support corporate sustainability. Single initiatives do not concretely address sustainability issues, but a full involvement of all company levels, activities, and tools is necessary as well as possible. The SEKEM case study shows that a sustainability-oriented purpose and strategy can be better operationalized when translated into management accounting, control, and reporting systems and tools. Starting from a clear corporate purpose and strategy, accounting must rediscover its function of communication, acting as a basis for dialogue between the various corporate actors. The management control system, on the other hand, has to consider the sustainable KPIs, alongside financial ones, with the aim of measuring and then reporting any economic, social, and ecological business impact. In other words, this case study highlights how, through management accounting and control systems, corporate purpose can be formalized in short- and medium-long term objectives and then translated in an operative line of action. This result can be better achieved when a holistic alignment process (rather than just overlapping) occurs, ensuring technical, organizational, and cultural integration. Finally, the paper reveals that corporate sustainability is a continuous and constant process that needs to be managed daily through an integrated approach. The concept of integration can clearly refer to the overlap of traditional managerial practices with sustainability-oriented ones, but not only that. Integration can be even more effective in addressing sustainability issues when it is referred to the alignment of business tools and functions. Regardless, this new concept of integration does not exclude the old one but rather reinforces it. At first, it is necessary to overlap traditional and sustainable 
management practices. Afterwards, managers have to align such reshaped practices to ensure the corporate sustainable growth.

This study opens the way to further considerations and empirical analyses regarding the processes of integration and alignment of managerial phases and tools, in order to ensure sustainable economic growth. Studying other business cases, also in other socioeconomic contexts, may help to identify new ways of managerial integration, also with reference to outside-in and twin-track approach perspectives.

Author Contributions: Conceptualization, S.C. and G.V.; Investigation, L.R.; Validation, S.C.; Writing-Original Draft Preparation, G.V. and L.R..; Writing-Review and Editing, S.C. and A.R.; Supervision, S.C. and A.R.

Funding: The present study was conducted without any public or private funding benefits.

Acknowledgments: The present study has been developed interacting with Maximilian Abouleish-Boes, Ph.D. (SEKEM Chief Sustainable Development Officer). Therefore, we are very grateful to Dr. Abouleish-Boes for his kind support and his useful explanations about corporate internal documents and data. Finally, we would also to thank Sigward Vonlaue, Ph.D. (Research and International Affairs of Heliopolis University) for his precious contribute aimed to improve our knowledge, during the interviews carried out, about the important and complex SEKEM socioeconomic and environmental activities.

Conflicts of Interest: The authors declare no conflicts of interest.

\section{Appendix A}

Table A1. SEKEM's sustainability KPI matrix.

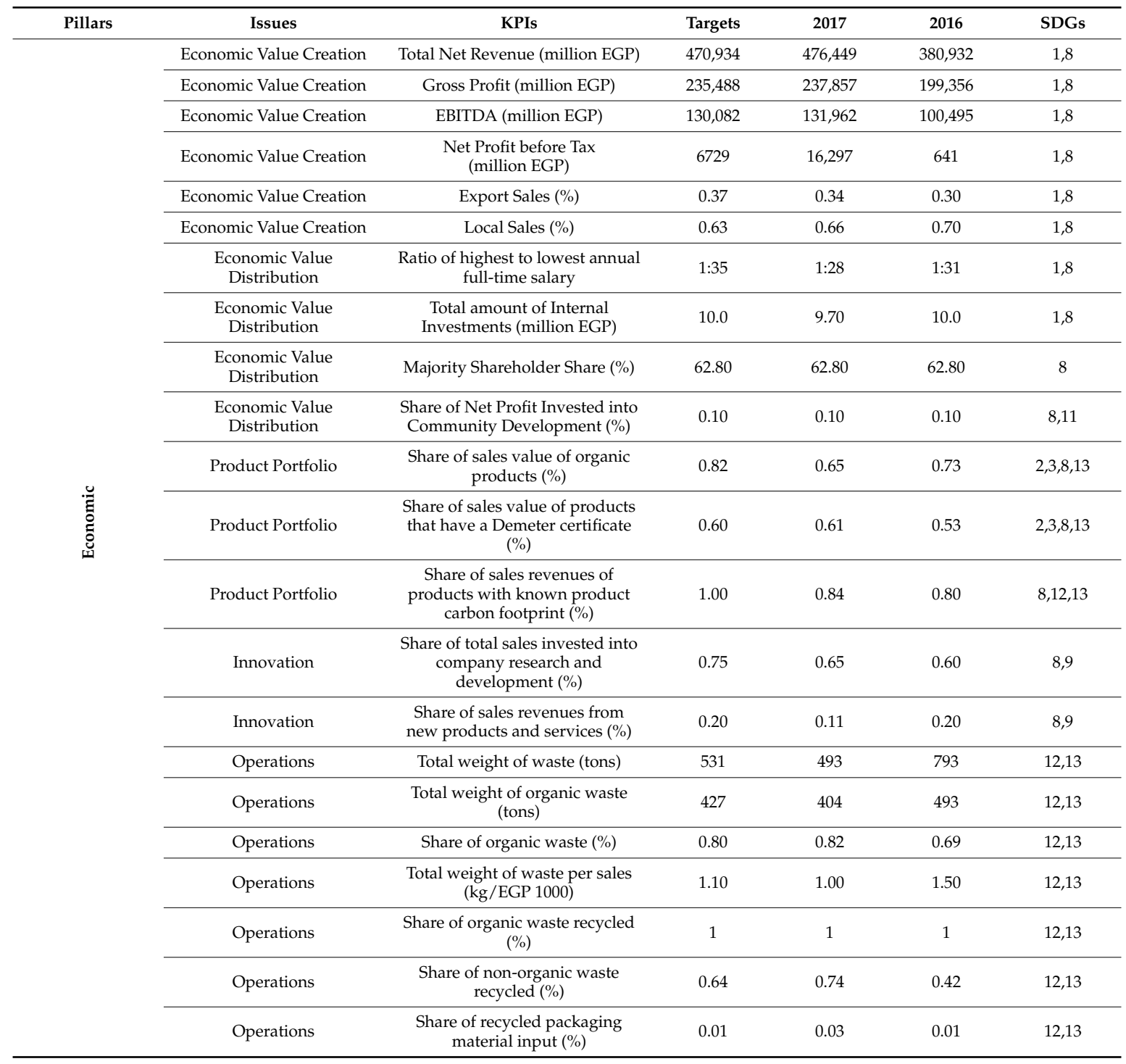


Table A1. Cont.

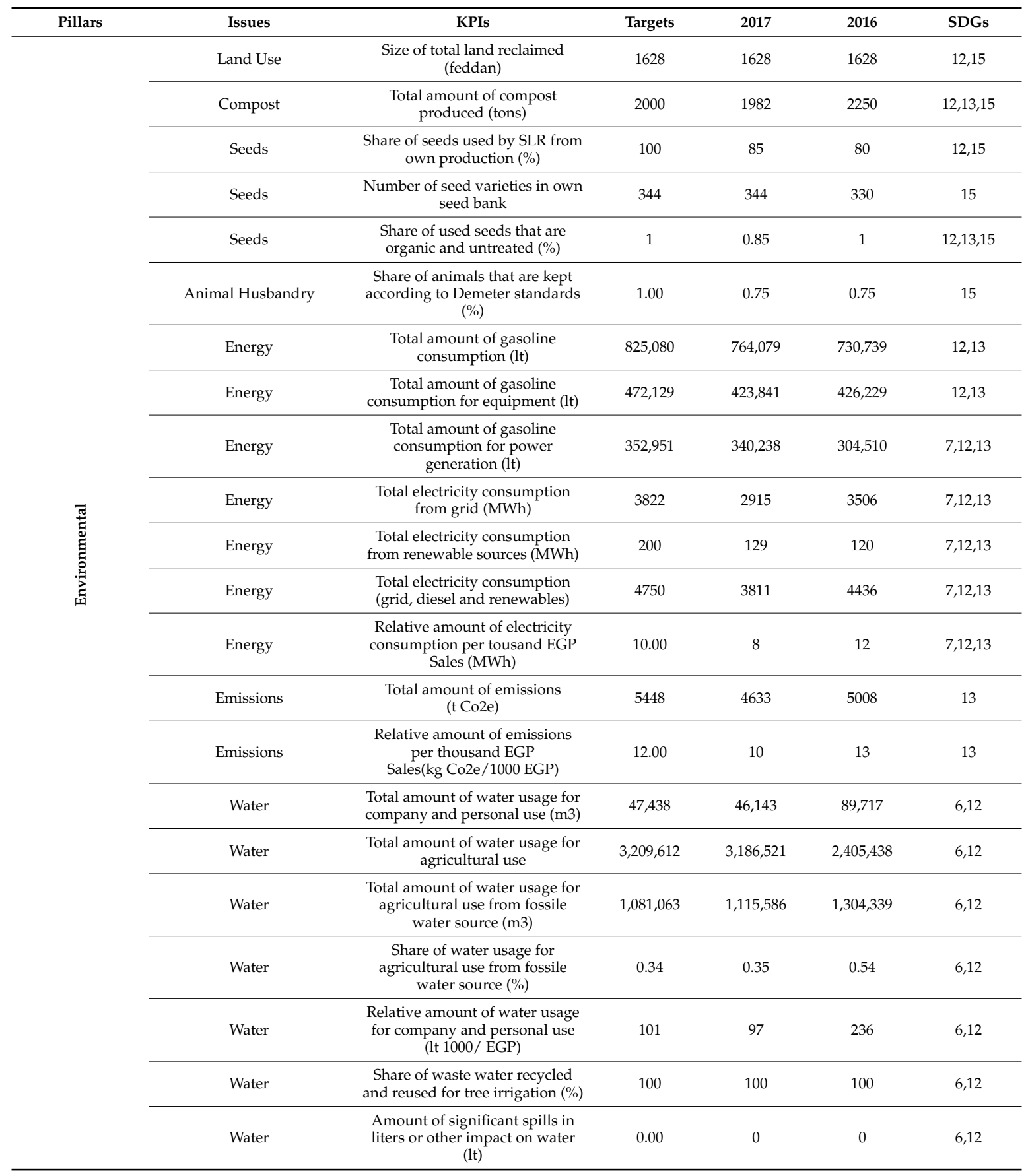


Table A1. Cont.

\begin{tabular}{|c|c|c|c|c|c|c|}
\hline Pillars & Issues & KPIs & Targets & 2017 & 2016 & SDGs \\
\hline \multirow{23}{*}{.]ّ̆ } & Workforce Composition & Number of Senior Managers & 14 & 11 & 11 & $1,8,10$ \\
\hline & Workforce Composition & Number of Middle Managers & 116 & 95 & 124 & $1,8,10$ \\
\hline & Workforce Composition & Number of Labourers & 683 & 587 & 574 & $1,8,10$ \\
\hline & Workforce Composition & Number of Daily Workers & 180 & 168 & 160 & $1,8,10$ \\
\hline & Workforce Composition & $\begin{array}{l}\text { Share of young employees } \\
\text { (below the age of } 36)(\%)\end{array}$ & 0.65 & 0.63 & 0.64 & $1,8,10$ \\
\hline & Workforce Diversity & $\begin{array}{l}\text { Share of females in total work- } \\
\text { force (excl. Daily Workers) (\%) }\end{array}$ & 0.26 & 0.25 & 0.22 & $1,5,8,10$ \\
\hline & Workforce Diversity & $\begin{array}{l}\text { Share of females in senior and } \\
\text { middle manager positions (\%) }\end{array}$ & 0.15 & 0.13 & 0.14 & $1,5,8,10$ \\
\hline & Loyalty and Motivation & Employee turnover (\%) & 0.07 & 0.0748 & 0.072 & $1,8,10$ \\
\hline & Loyalty and Motivation & $\begin{array}{l}\text { Total number of part time } \\
\text { workers }\end{array}$ & 37.00 & 38 & 62 & $1,8,10$ \\
\hline & Loyalty and Motivation & $\begin{array}{c}\text { Share of workforce that works } \\
\text { part time }(\%)\end{array}$ & 0.05 & 0.03 & 0.05 & $1,8,10$ \\
\hline & Loyalty and Motivation & $\begin{array}{c}\text { Estimated share of } \\
\text { non-monetary benefits of overall } \\
\text { salaries }(\%)\end{array}$ & 0.10 & 0.1 & 0.09 & $1,8,10$ \\
\hline & $\begin{array}{l}\text { Advocacy for Sustainable } \\
\text { Development }\end{array}$ & $\begin{array}{l}\text { Number of events concerning } \\
\text { SD where SEKEM } \\
\text { representatives played an active } \\
\text { role }\end{array}$ & n.a. & 36 & 26 & $1,8,10,17$ \\
\hline & $\begin{array}{l}\text { Advocacy for Sustainable } \\
\text { Development }\end{array}$ & $\begin{array}{c}\text { Number of awards related to } \\
\text { sustainable development } \\
\text { received }\end{array}$ & 0.00 & 0 & 0 & $1,8,10,17$ \\
\hline & $\begin{array}{l}\text { Advocacy for Sustainable } \\
\text { Development }\end{array}$ & $\begin{array}{l}\text { Number of articles in renowned } \\
\text { publications on SEKEM and } \\
\text { sustainable development per } \\
\text { year }\end{array}$ & 250 & 307 & 288 & 4,11 \\
\hline & $\begin{array}{l}\text { Advocacy for Sustainable } \\
\text { Development }\end{array}$ & $\begin{array}{l}\text { Number of active membership } \\
\text { in organizations relevant for } \\
\text { sustainable development }\end{array}$ & 13 & 13 & 13 & 17 \\
\hline & Health and Safety & $\begin{array}{c}\text { Number of employee visits at } \\
\text { the Medical Center }\end{array}$ & 6000 & 6855 & 5663 & $3,8,10$ \\
\hline & Health and Safety & $\begin{array}{l}\text { Number of other visits at the } \\
\text { Medical Center }\end{array}$ & $\mathrm{n} / \mathrm{a}$ & 38,557 & 38,542 & $3,8,10$ \\
\hline & Health and Safety & $\begin{array}{c}\text { Total Number of Medical Center } \\
\text { visits }\end{array}$ & $\mathrm{n} / \mathrm{a}$ & 45,412 & 44,205 & $3,8,10$ \\
\hline & Health and Safety & $\begin{array}{c}\text { Share of employees with private } \\
\text { health insurance }(\%)\end{array}$ & 0.25 & 0.2519 & 0.26 & $3,8,10$ \\
\hline & Health and Safety & $\begin{array}{l}\text { Total number of working days } \\
\text { lost due to sick leave etc. }\end{array}$ & 2000 & 1720 & 2320 & $3,8,10$ \\
\hline & Health and Safety & Absentee rate (\%) & 1.40 & 1.9 & 1.8 & $3,8,10$ \\
\hline & Health and Safety & $\begin{array}{c}\text { Total number of work related } \\
\text { injuries }\end{array}$ & 0.00 & 4 & 5 & $3,8,10$ \\
\hline & Health and Safety & Number of fatal injuries & 0.00 & 0 & 0 & $3,8,10$ \\
\hline
\end{tabular}


Table A1. Cont.

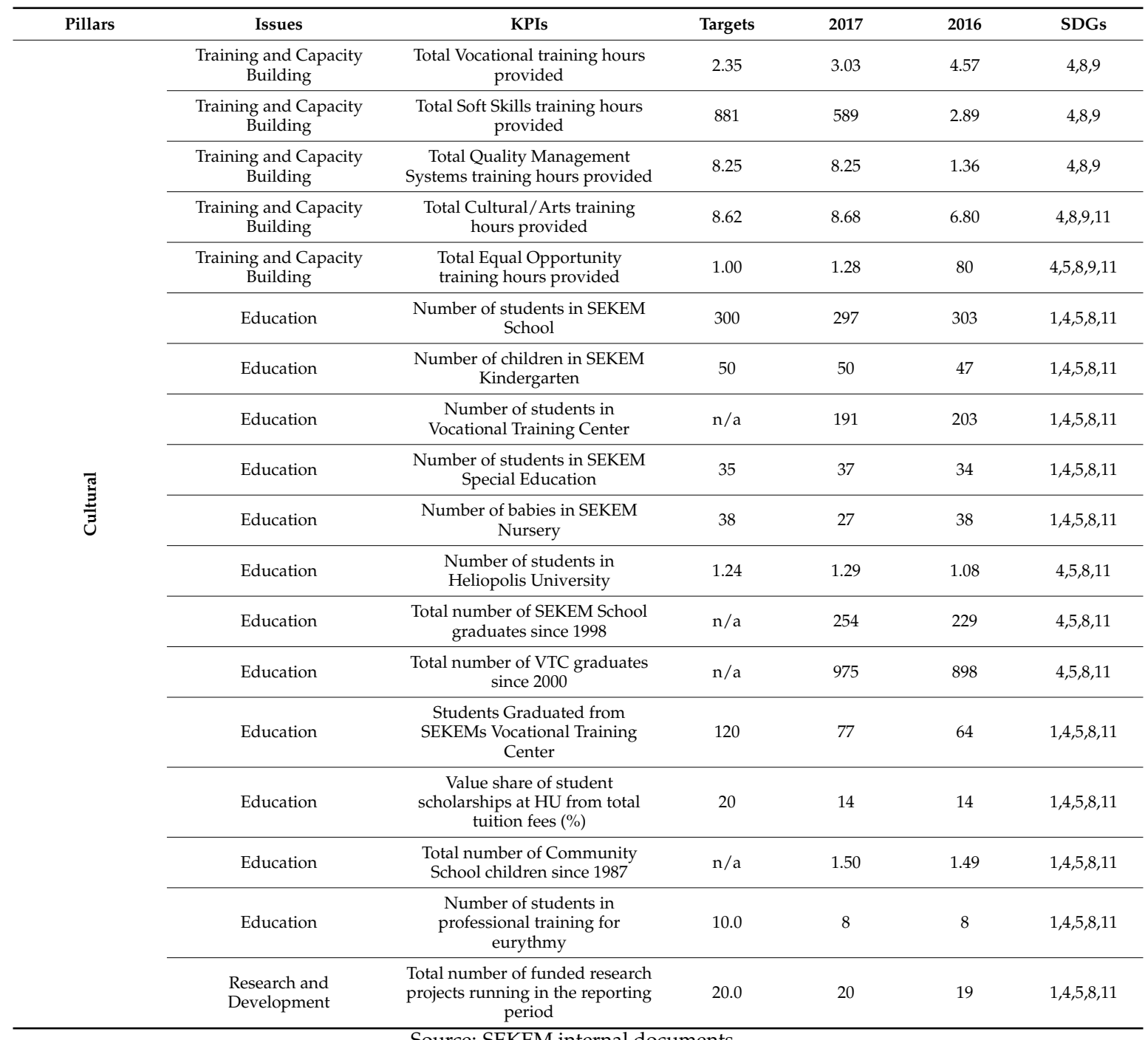


Dimension

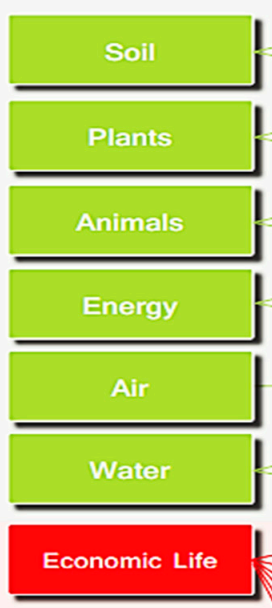

Societal Life

Cultural Life
Performance Aspect

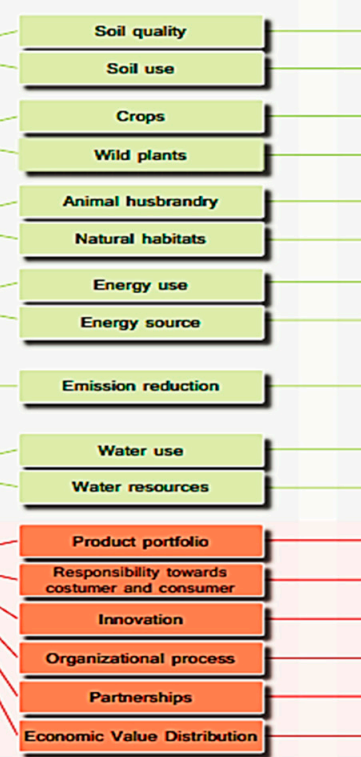

ther nome

Health

Diversity

Employee loyalty
and motivation

Governance and Compllance
Sustainobicacy Dev Development

Training and education

Self-fulfilment and vitenty

Cuttural Rights

Research and development

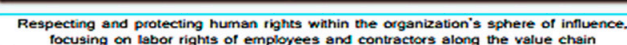
Woxking Eme - Insurgencies - Non-monetary bene
Goal of Performance Aspect

Sub-Performance Aspect

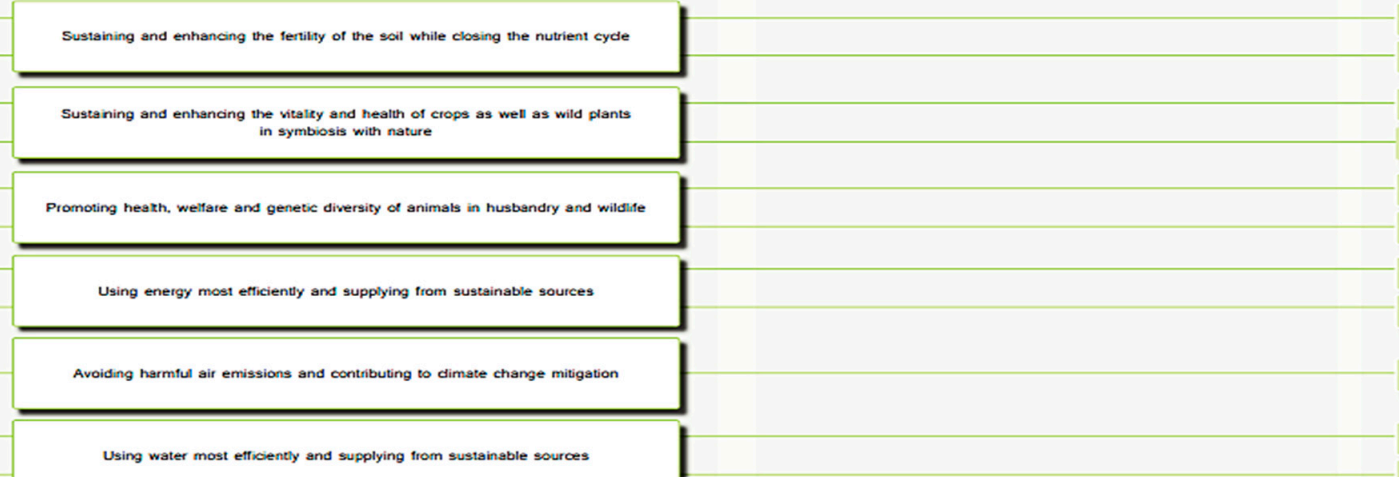

Using water most etticenty and supplying from sustisinsble Sources

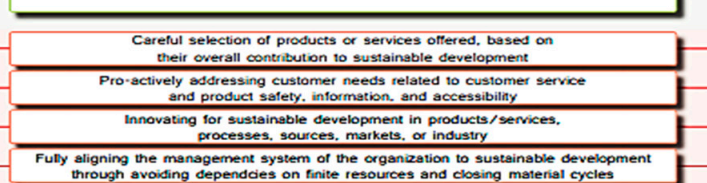

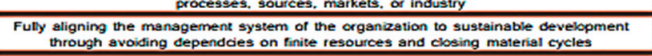

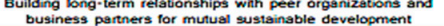

Creating economic value while ensuring its tair and sustainater

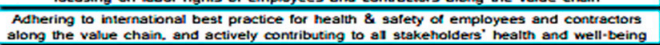

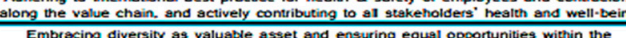

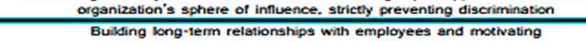

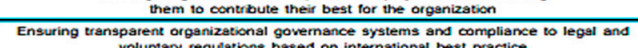

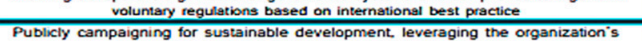
Tor

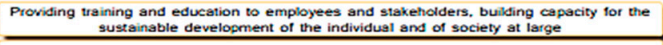
Supponting the individual to develop an atrurue towards ser-cetermination and serstaction

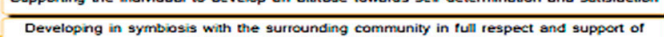

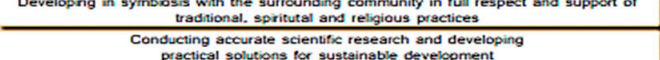

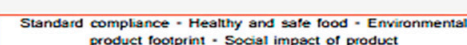

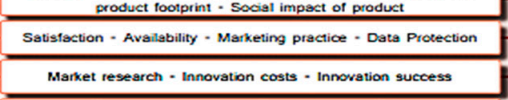
Mansogement system . Dependency on finili
resoutces and etriciency. waste

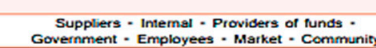
Risk awareness of non-compliance - Control within organization -

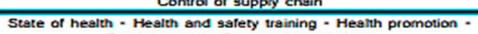

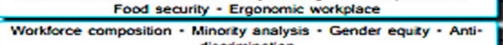
discliminstion
Employee fuctuation - Contracts -

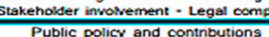

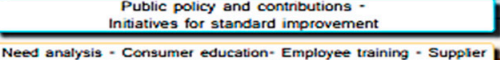
Need analysis - Consumer education- Employee training - Suppier
tuaning

Mental and social vatahy - satiataction - ocher social projects

Source: SEKEM internal documents

Figure A1. SEKEM qualitative sustainability balance scorecard.
Evaluation

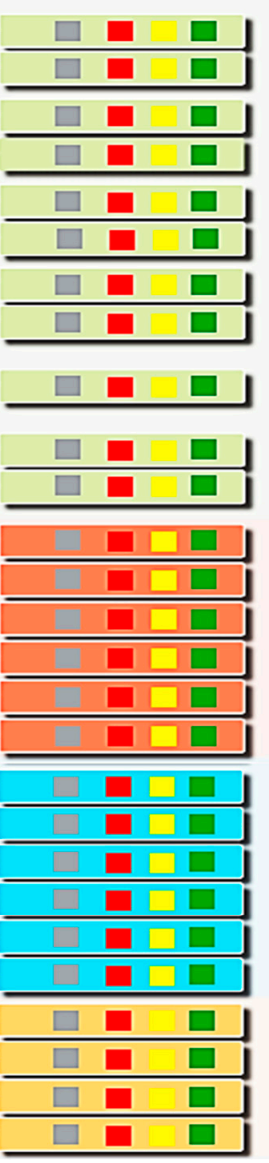




\section{References}

1. UN. Transforming our world: The Agenda 2030 for Sustainable Development. 2015. Available online: http:/ / www.un.org/ga/search/view_doc.asp?symbol=A/RES/70/1\&Lang=E (accessed on 15 June 2018).

2. Porter, M.E.; Kramer, M.R. The link between competitive advantage and corporate social responsibility. Harvard Bus. Rev. 2006, 84, 78-92.

3. Jasch, C.; Stasiškienè, Ž. From Environmental Management Accounting to Sustainability Management Accounting. Environ. Res. Eng. Manag. 2005, 34,77-88.

4. Adams, D. The power of corporate purpose. In The Reputable Firm: How Digitalization of Communication Is Revolutionizing Reputation Management; Aula, P., Heinonen, J., Eds.; Springer: Cham, Switzerland, 2015; ISBN 9783319220086.

5. Freeman, R.E. Strategic Management: A Stakeholder Approach; Pitman: Boston, MA, USA, 1984; ISBN 978-0-521-15174-0.

6. Donaldson, T.; Preston, L.E. The Stakeholder Theory of the Corporation: Concepts, Evidence, and Implications. Acad. Manag. Rev. 1995, 20, 65-91. [CrossRef]

7. Schaltegger, S.; Wagner, M. Managing sustainability performance measurement and reporting in an integrated manner. Sustainability accounting as the link between the sustainability balanced scorecard and sustainability reporting. In Sustainability Accounting and Reporting; Schaltegger, S., Bennett, M., Burritt, R., Eds.; Springer: Dordrecht, The Netherlands, 2006; pp. 681-697.

8. Falle, S.; Rauter, R.; Engert, S.; Baumgartner, R.J. Sustainability management with the sustainability balanced scorecard in SMEs: Findings from an Austrian case study. Sustainability 2016, 8, 545. [CrossRef]

9. Gond, J.P.; Grubnic, S.; Herzig, C.; Moon, J. Configuring management control systems: Theorizing the integration of strategy and sustainability. Manag. Account Res. 2012, 23, 205-223. [CrossRef]

10. Battaglia, M.; Passetti, E.; Bianchi, L.; Frey, M. Managing for integration: A longitudinal analysis of management control for sustainability. J. Clean. Prod. 2016, 136, 213-225. [CrossRef]

11. Maas, K.; Schaltegger, S.; Crutzen, N. Integrating corporate sustainability assessment, management accounting, control, and reporting. J. Clean. Prod. 2016, 136, 237-248. [CrossRef]

12. Adams, C.A.; Frost, G.R. Integrating sustainability reporting into management practices. Account. Forum 2008, 32, 288-302. [CrossRef]

13. Riccaboni, A.; Leone, E.L. Implementing strategies through management control systems: The case of sustainability. Int. J. Prod. Perform. Manag. 2010, 59, 130-144. [CrossRef]

14. Giovannoni, E.; Maraghini, M.P. The challenges of integrated performance measurement systems: Integrating mechanisms for integrated measures. Account. Audit. Accoun. 2013, 26, 978-1008. [CrossRef]

15. Burritt, R.L.; Schaltegger, S. Sustainability accounting and reporting: Fad or trend? Account. Audit. Accoun. 2010, 23, 829-846. [CrossRef]

16. De Villiers, C.; Rouse, P.; Kerr, J. A new conceptual model of influences driving sustainability based on case evidence of the integration of corporate sustainability management control and reporting. J. Clean. Prod. 2016, 136, 78-85. [CrossRef]

17. Seelos, C.; Mair, J. Social entrepreneurship: Creating new business models to serve the poor. Bus. Horizons 2005, 48, 241-246. [CrossRef]

18. Mair, J.; Marti, I. Social entrepreneurship research: A source of explanation, prediction, and delight. J. World Bus. 2006, 41, 36-44. [CrossRef]

19. Rimac, T.; Mair, J.; Battilana, J. Social entrepreneurs, socialization processes, and social change: The case of SEKEM. In Using a Positive Lens to Explore Social Change and Organizations: Building a Theoretical and Research Foundation; Golden-Biddle, K., Dutton, J., Eds.; Routledge: New York, NY, USA, 2012; pp. 71-89, ISBN 978-0-415-87885-2.

20. Littlewood, D.; Holt, D. How social enterprises can contribute to the Sustainable Development Goals (SDGs)-A conceptual framework. In Entrepreneurship and the Sustainable Development Goals; Apostolopoulos, N., Al-Dajani, H., Holt, D., Jones, P., Newbery, R., Eds.; Emerald Publishing Limited: Bingley, UK, 2018; pp. 33-46, ISBN 978-1-78756-376-6.

21. Haanaes, K.; Michael, D.; Jurgens, J.; Rangan, S. Making sustainability profitable. Harvard Bus. Rev. 2013, 91, 110-115. 
22. Horngren, C.T.; Sundem, G.L.; Schatzberg, J.O.; Burgstahler, D. Introduction to Management Accounting, 16th ed.; Pearson: New York, NY, USA, 2013; ISBN 978-0133058819.

23. Gray, R.; Bebbington, J. Environmental accounting, managerialism and sustainability: Is the planet safe in the hands of business and accounting? In Advances in Environmental Accounting \& Management; Emerald Group Publishing Limited: Bingley, UK, 2000; Volume 1, pp. 1-44, ISBN 978-0-76230-334-2.

24. Gwilliam, D.; Jackson, R.H.G. Fair value in financial reporting: Problems and pitfalls in practice: A case study analysis of the use of fair valuation at Enron. Account. Forum 2008, 32, 240-259. [CrossRef]

25. Schaltegger, S.; Burritt, R.L. Sustainability accounting for companies: Catchphrase or decision support for business leaders? J. World Bus. 2010, 45, 375-384. [CrossRef]

26. Figge, F.; Hahn, T.; Schaltegger, S.; Wagner, M. The sustainability balanced scorecard—Linking sustainability management to business strategy. Bus. Strateg. Environ. 2002, 11, 269-284. [CrossRef]

27. Bebbington, J.; Unerman, J.; O'Dwyer, B. Introduction to sustainability accounting and accountability. In Sustainability Accounting and Accountability, 2nd ed.; Bebbington, J., Unerman, J., O’Dwyer, B., Eds.; Routledge: Abingdon, UK, 2014; ISBN 978-0415695572.

28. Merchant, K.A.; Riccaboni, A. Il Controllo di Gestione; McGraw-Hill: Milano, Italy, 2001; ISBN 978-8-83-867385-6.

29. Berry, A.J.; Broadbent, J.; Otley, D.T. (Eds.) Management Control: Theories, Issues and Practices; Macmillan International Higher Education: London, UK, 2016; ISBN 979-0-333-57243-6.

30. Otley, D. The contingency theory of management accounting and control: 1980-2014. Manag. Account. Res. 2016, 31, 45-62. [CrossRef]

31. Kaplan, R.S.; Norton, D.P. Mastering the management system. Harvard Bus. Rev. 2008, 86, 62.

32. Schaltegger, S. Sustainability management control. In Environmental Management Accounting and Supply Chain Management; Springer: Dordrecht, The Netherlands, 2011; pp. 337-352, ISBN 978-94-007-1389-5.

33. Schaltegger, S.; Burritt, R. Contemporary Environmental Accounting; Greenleaf: Sheffield, UK, 2000.

34. Henri, J.-F.; Journault, M. Eco-control: The influence of management control systems on environmental and economic performance. Account. Org. Soc. 2010, 35, 63-80. [CrossRef]

35. Simons, R. Levers of Control, How Managers Use Innovative Control Systems to Drive Strategic Renewal; Harvard Business School Press: Boston, MA, USA, 1995.

36. Arvidsson, $\mathrm{S}$. Disclosure of non-financial information in the annual report: A management-team perspective. J. Intellect. Cap. 2011, 12, 277-300. [CrossRef]

37. Schaltegger, S.; Bennett, M.; Burritt, R. (Eds.) Sustainability Accounting And reporting; Springer Science \& Business Media: Dordrecht, The Netherlands, 2006; Volume 21, ISBN 978-1-4020-4974-3.

38. Dumay, J.; Dai, T. Integrated thinking as a cultural control? Meditari Account. Res. 2017, 25, 574-604. [CrossRef]

39. Manes-Rossi, F.; Tiron-Tudor, A.; Nicolò, G.; Zanellato, G. Ensuring More Sustainable Reporting in Europe Using Non-Financial Disclosure-De Facto and De Jure Evidence. Sustainability 2018, 10, 1162. [CrossRef]

40. Loh, L.; Thomas, T.; Wang, Y. Sustainability reporting and firm value: Evidence from Singapore-Listed companies. Sustainability 2017, 9, 2112. [CrossRef]

41. Kolk, A. Sustainability, accountability and corporate governance: Exploring multinationals' reporting practices. Bus. Strateg. Environ. 2008, 17, 1-15. [CrossRef]

42. Lozano, R.; Nummert, B.; Ceulemans, K. Elucidating the relationship between sustainability reporting and organisational change management for sustainability. J. Clean. Prod. 2016, 125, 168-188. [CrossRef]

43. GRI. About sustainability reporting. Available online: https://www.globalreporting.org/information/ sustainability-reporting/Pages/default.aspx (accessed on 3 September 2018).

44. Gonzalez Gonzalez, J.M.; Zamora Ramírez, C. Organisational communication on climate change: The influence of the institutional context and the adoption pattern. Int. J. Clim. Chang. Str. 2016, 8, 286-316. [CrossRef]

45. Yin, R.K. Case Study Research and Applications: Design and Methods; Sage publicatIons: Thousand Oaks, CA, USA, 2017; ISBN 9781506336169.

46. Eisenhardt, M.K. Building theories from case study research. Acad. Manag. Rev. 1989, 14, 532-550. [CrossRef]

47. Siggelkow, N. Persuasion with case studies. Acad. Manag. J. 2007, 50, 20-24. [CrossRef] 
48. Burns, J.; Scapens, R.W. Conceptualising management accounting change: An institutional framework. Manag. Account. Res. 2000, 11, 3-25. [CrossRef]

49. Scapens, R.W. Researching management accounting practice: The role of case study methods. Br. Account. Rev. 1990, 22, 259-281. [CrossRef] 